\title{
The Impact of Job Insecurity on Employee Happiness at Work: A Case of Robotised Production Line Operators in Furniture Industry in Lithuania
}

\author{
Živilè Stankevičiūtė *(D), Eglè Staniškienè and Joana Ramanauskaitė \\ School of Economics and Business, Kaunas University of Technology, LT-44249 Kaunas, Lithuania; \\ egle.staniskiene@ktu.lt (E.S.); joana.ramanauskaite@ktu.lt (J.R.) \\ * Correspondence: zivile.stankeviciute@ktu.lt; Tel.: +370-650-11-505
}

Citation: Stankevičiūtè, Ž.;

Staniškienè, E.; Ramanauskaitè, J. The Impact of Job Insecurity on Employee Happiness at Work: A Case of Robotised Production Line Operators in Furniture Industry in Lithuania. Sustainability 2021, 13, 1563. https:// doi.org/10.3390/su13031563

Academic Editors: Carla Curado and Rytis Maskeliunas

Received: 5 December 2020

Accepted: 29 January 2021

Published: 2 February 2021

Publisher's Note: MDPI stays neutral with regard to jurisdictional claims in published maps and institutional affiliations.

Copyright: (c) 2021 by the authors. Licensee MDPI, Basel, Switzerland. This article is an open access article distributed under the terms and conditions of the Creative Commons Attribution (CC BY) license (https:// creativecommons.org/licenses/by/ $4.0 /)$.

\begin{abstract}
As a result of intensive robotisation over the past decade, employees have been constantly experiencing job insecurity, a term which refers to the perceived threat of job loss and the worries related to this threat. Previous studies have supported the detrimental effect of job insecurity on employees; however, the focus on happiness at work is still missing, despite the notion that a happy employee is essentially contributing to sustainable business performance. Trying to narrow the gap, the paper aims at revealing the linkage between job insecurity and happiness at work and its dimensions, namely job satisfaction, affective organisational commitment, and work engagement. Building on the hindrance stressor dimension of the stress model, and conservation of resources and psychological contract theories, the paper claims that a negative relationship exists between the constructs. Quantitative data were collected in a survey of robotised production line operators working in the furniture sector in Lithuania. As predicted, the results revealed that job insecurity had a negative impact on happiness at work as a higher-order construct and all of its dimensions. This finding should be taken seriously by organisations creating a robotised production environment while striving for sustainability.
\end{abstract}

Keywords: job insecurity; happiness at work; job satisfaction; work engagement; affective organisational commitment; robotisation; furniture industry

\section{Introduction}

Over the past few decades, a growing conviction has emerged that our society is entering a new phase, called "robot society" [1], when robots create a fundamental shift in economies and transform the nature of work [2]. Evidence from various industries demonstrates that recently, a growing number of companies have been adapting and using robots in search for lower costs, faster production time, expanded production/service capacity, and ultimately improved competitiveness [3,4]. Given this, the concern about the future employability of human workers is increasing, addressing the question of whether robots will largely be used as complements or substitutes to human labour [5-7]. Regarding this concern, employees feel that the future of their employment is at stake [8-11]. This experience is called job insecurity, referring to the overall concern of employees about the continued existence of their jobs in the future [12-14]. As job insecurity is expected to continue and remain inevitable in the contemporary world [15], extensive research has been carried out on the impact of job insecurity on employees and organisations, reporting mainly detrimental effects [16-19]. Such negative effects do not correspond to the essence of sustainability but rather contradict it, as sustainability refers to the idea that organisations serve the needs of multiple stakeholders and have a broader range of obligations besides economic. Thus, social aspects, more specifically the perceived threat of job loss, should be taken into consideration by organisations when striving for sustainability. 
While previous literature in the job insecurity domain has provided insights into the relationship between job insecurity and four outcome types (employee health and wellbeing; attitudes towards job and organisation; performance and behavioural outcomes; and interpersonal contagion and spillover effects) [8], several gaps nonetheless remain. First, considering employee attitudes towards the job and organisation as the outcome of job insecurity, the focus has been mainly on separate attitudes such as work engagement or job satisfaction [8]. However, happiness at work as a higher-order construct has received no attention [20]. Incidentally, this is despite the overall growing interest in happiness at work, as happiness is a fundamental state that most people aim to achieve in their lives [21]. Happiness relates to how people experience and appraise their lives in general [22]. Considering that out of 700,000 h constituting their life, people work 56,000 h [23], it seems worth addressing happiness at work with more frequency and magnitude. Although the literature provides no consensus regarding the dimensions of happiness at work, Fisher [24] introduced more than 10 constructs that have something to do with being happy. In line with the above, the current paper aims at narrowing the existing gap by exploring not only the impact job insecurity has on attitudes of individual employees, but also on happiness at work, treating it as a second-order construct, which consists of three dimensions, namely job satisfaction, affective organisational commitment, and work engagement.

Second, the main body of research on job insecurity has been conducted in the service sector [25], media sector [26], and university sector [27], or has explored the job insecurity of white-collar employees [28]. Meanwhile, job insecurity experienced by the manufacturing workers has been studied to a somewhat lesser extent [29] despite the notion that the current jobs in manufacturing are in danger of disappearing or being taken over by robots [30], as these jobs include repetitive, dangerous tasks and are subject to strict algorithmisation [3]. Trying to narrow the gap, the research was conducted in the furniture sector in Lithuania, characterised by high intensity of forward-going robotisation. The sample consisted of robotised production line operators. This means that job insecurity analysed in this paper reflects the experience of respondents while they have already been affected by automationrobotisation related solutions, as they work together with robots. Generally speaking, the paper addresses a specific context and sample and by doing this, echoes the concerns voiced in several previous studies $[11,26]$ not to focus only on Western European countries or Asia, but also to turn to the emerging markets.

Third, drawing upon previous literature, it seems that stress theory [31], conservation of resources (COR) theory [32], and psychological contract theory [33] are the main theoretical approaches used to explain the relationship between job insecurity and work engagement or other employee attitudes. While addressing how job insecurity affects happiness at work, the current paper limits its focus to all these theories.

Considering the gaps illustrated above, the aim of the paper is to reveal the linkage between job insecurity and happiness at work and its dimensions in terms of job satisfaction, affective organisational commitment, and work engagement among the robotised production line operators in the Lithuanian furniture sector. In doing this, the paper seeks to answer the following: (a) whether and to what extent do the workers feel job insecurity? (b) whether and to what extent are the workers happy at work? (c) whether and to what extent do the workers feel job satisfaction, affective organisational commitment, and are engaged? (d) will job insecurity impact happiness at work and its three dimensions? As was previously mentioned, in order to answer these questions, this paper analyses data from the survey carried out in the companies of the furniture sector, which is far-advanced in using robots and automation solutions. The sample consisted of operators working on robotised production lines. The research is based on job insecurity perceived by employees.

The paper is supposed to make three main contributions to the existing body of knowledge. First, the paper enriches the job insecurity literature by identifying how it affects happiness at work. Second, the paper promotes employee well-being, as happiness at work is one of its dimensions [34]. Actually, by managing the threat of unemployment, harmful consequences for employees are mitigated and human sustainability is fostered. 
This is extremely relevant to the corporate sustainability debate, since business takes responsibility for all its stakeholders [35,36]. Third, with the use of valuable first-hand data, the paper tackles a specific context, namely the Lithuanian furniture sector, which is far-advanced in using robots. This allows for expanding the pool of empirical findings, which mainly consists of findings from non-manufacturing companies in Western Europen and Asian settings. Summing up, the novelty of the paper is expressed through the use of happiness at work as a higher-order construct and through the research context, using the sample of robotised production line operators.

The remainder of the paper is structured as follows. The theoretical part introduces robotisation and its implications for Lithuania and its furniture sector, gives an overview of the literature on the changing nature of work and describes job satisfaction, affective organisational commitment, work engagement and, finally, happiness at work. Later, the hypotheses are developed. Then, the research method applied is described. The empirical results and discussion come further. Finally, conclusions are drawn.

\section{Theoretical Background}

\subsection{Robotisation and Its Implications for Lithuania and Its Furniture Sector}

There are two sides to the medal of automation and robotisation in the workplaces: negative while reducing the number of jobs for humans and positive while creating and offering new jobs. Generally speaking, some of the routine activities that are too harmful or too difficult for a person to perform will be taken by a robot, process automation, or artificial intelligence [37,38] as a result of Industry 4.0 [39]. It is estimated in studies (with widely varying results) that the portion of jobs that could be automated in the future is between a loss of two billion to creating 375 million new workplaces by 2025-2030 [40]. This wave of automation poses a risk to all employees; however, women, people with lower education, and people in lower-wage occupations overall will be most affected [37]. A study carried out by Digybite and published by the European Commission found that 74\% of respondents believed that artificial intelligence would eliminate more workplaces than it would create; $72 \%$ believed that "robots steal peoples' jobs"; $42 \%$ could transfer at least some of their work activities to robots [41]. From the more positive side of technological advancement, it should be admitted that two million new workplaces have been created due to the application of digital innovations in the EU over the last decade [40].

Turning to robots, they are classified by their operation types and interaction with humans, leading to the notion that industrial robots refer to just one type of robot. Industrial robots can be defined as proposed by Appleton \& Williams [42] adapting the definition of the International Standards Organisation: "an automatic servo controlled programmable multifunctional manipulator having multiple axes, capable of handling materials, parts, tools, or specialized devices through variable programmed operations for the performance of variety of tasks" (p. 3). When it comes to manufacturing, production process automation and robotisation allow for reducing material waste in the production and chance of error; increase the productivity; increase the safety of employees by having robots perform routine or strenuous tasks or work in dangerous environments, thus contributing to sustainability.

Regarding the degree of robotisation, roughly around 400,000 units of robots have been installed per year worldwide over the last two years and this number dropped by $12 \%$ for the first time in six years in 2019 [43,44]. Nevertheless, the growth of automation and robotisation worldwide might increase the efficiency of the companies, simultaneously increasing the concern for employee job security.

Speaking of Lithuania, the country where the survey was conducted, it should be recognised that Lithuania is a special country, since it survived a long period of occupation and experienced privatisation and goods famine [45]. Thirty years ago, Lithuania restored its independence, and fifteen years ago it joined the European Union (EU). According to the European Commission, during recent years, Lithuania has experienced positive economic changes; however, acute problems such as income inequality, poverty, and social exclusion remain [46]. The income of the richest $20 \%$ of the population is 7.1 times higher than the 
income of the poorest $20 \%$, compared to 5.17 times for the EU as a whole. Moreover, as much as $28.3 \%$ of the population is at risk of poverty or social exclusion, well above the EU average of $21.9 \%$ [46]. These examples illustrate that Lithuania faces challenges regarding social sustainability. However, the situation in the field of environmental sustainability is not better either. Environmental sustainability in Lithuania is low overall, the main contributing factors being low resource efficiency, little progress on the circular economy and high pollution levels from fossil fuel consumption in transport [46]. When it comes to digital sustainability, Lithuania also needs some progress as, for instance, the density of the robots in Lithuania is among the lowest in the EU [47].

Lithuanian industrial companies seem to understand the challenges they are facing-the demand for robotisation solutions currently exceeds the supply [48,49], although only 3\% of Lithuania-based enterprises employ robotic solutions [50]. UAB Robotex is one of the largest companies installing robots and automation solutions in Lithuania. The company is engaged in the integration of robots in industrial enterprises in order to increase the efficiency, ensure high continuous product quality, and reduce the production costs. Their annual sales double every year, having installed 16 robots in 2018 [48]. Another example could be UAB Terekas, producing automated and robotised PET packaging lines, which made and sold 21 machines in 2017 [51]. Furthermore, ship builders of UAB Vakaru Laivu Gamykla company group use the virtual space for design works, where all projects can be visualised and only after checking the efficiency of the product itself and its production technology in the virtual space can the production begin, aiming at elimination of all errors before production, thus ensuring efficient production and obtaining the best result [52]. Nevertheless, there were only 2 industrial robots per 10 thousand inhabitants in Lithuania in 2017, whereas in Finland, this indicator is already about 60 [53]. This notwithstanding, the European Union endorses the initiatives for boosting new digital transformation and encouraging countries to build platforms for cooperation regarding Industry 4.0 [54]. Lithuania is one of 15 member states having a platform that unites all the major stakeholders from various sectors and functions as the main consensus building apparatus in the Lithuanian industrial ecosystem for digitalisation [55].

Furniture industry is one of the oldest wood processing industries in Lithuania. It has long-standing traditions, uses innovative production methods making high quality furniture, and applies high-tech solutions. It is one of the most competitive and highly developed manufacturing industries in Lithuania, with its staff possessing the appropriate qualifications and competencies [38]. The sector's remarkable integration into the global economy can be substantiated by the fact that $69.4 \%$ of furniture produced in Lithuania were exported to the EU market in 2019 [56]. Overall, in 2015, Lithuanian furniture industry created $2.4 \%$ of national GDP and $9.7 \%$ of GDP of the manufacturing sector, with the value of production approximated at 1.4 billion euros [57]. In 2019, the value of sales of goods and works performed in the sector increased by $20 \%$ [56]. Lithuanian furniture industry shares around $0.1 \%$ of the market realized revenue (worldwide US $\$ 1417 \mathrm{bn}$ ) [58]. The main indicators of Lithuanian furniture industry are stated in Table 1.

Table 1. Main indicators, 2015 [57].

\begin{tabular}{cc}
\hline Main Indicators & Number \\
\hline Operating companies & 872 \\
Number of employees & 27,724 \\
Production value & $€ 1.4 \mathrm{bn}$ \\
Added value & $€ 391 \mathrm{mill}$ \\
Export of goods of Lithuanian origin & $€ 1.2 \mathrm{bn}$ \\
Investments in tangible assets & $€ 61.5 \mathrm{mill}$ \\
\hline
\end{tabular}

The workforce of the Lithuanian furniture industry is also facing robotisation issues; it is estimated that over $60 \%$ of workforce are at risk in Lithuania because of automation, with $20 \%$ of them facing a high risk of significant change (more than $70 \%$ probability) [59]. $3 \mathrm{D}$ printers might easily carry out the production of furniture that is designed by algo- 
rithms [58]. Nevertheless, Lithuania is highly dependent on IKEA, which is the main driver of the innovation and progress of Lithuanian furniture industry, making it more cost- and labour-efficient, but also posing higher risks that are brought on by the lack of market diversification [60]. However, it is believed that the Lithuanian furniture industry will double in size in the coming several years because of the ongoing clusterisation [61]. Summing up, the ambition is that the Lithuanian furniture industry is and should remain one of the most significant and highest value-added sectors of the Lithuanian economy, as well as of the labour market [38].

\subsection{Job Insecurity}

Since the concept of job insecurity was introduced, multiple definitions of it have been provided. For instance, Greenhalgh and Rosenblatt [62] describe job insecurity as "the perceived powerlessness to maintain desired continuity in a threatened job situation" (p. 438). According to Rosenblatt and Ruvio [63], job insecurity is perceived as "an overall concern about the future existence of the job" (p. 587). Sverke et al. [13] define the construct as "subjectively experienced anticipation of a fundamental and involuntary event related to job loss" (p. 243). One of the more frequently quoted definitions belongs to De Witte [64] arguing that job insecurity is "the perceived threat of job loss and the worries related to that threat" (p. 1). A comprehensive overview of definitions provided by Shoss [18] suggests that some of them treat job insecurity as multi-dimensional, differentiating between quantitative (threats to the continuation or loss of the job itself), and qualitative (threats to continued existence of valued job features) job insecurity [64-66]. Further, another distinction is often made between cognitive and affective job insecurity $[19,64]$. Cognitive job insecurity implies the perceived threat to the continuity of one's employment and/or to the features of the job (e.g., deterioration of working conditions), whereas affective job insecurity captures the emotional reactions to the perceived threat to one's job (e.g., worry, concern or anxiety) [9].

Although scholars differ in the way they define job insecurity, it seems that the various definitions have common conceptual components. First, job insecurity is a subjective experience resulting from an individual's perception and interpretations of the actual work environment [14,67]. Hence, the same objective situation (e.g., previous redundancy or a decline in demand for the goods the company is producing) may be interpreted in various ways by different employees. Some of them may feel insecure although their job continuity is ('objectively speaking') not in danger, while others may feel secure about their jobs, even though they will be laid off soon afterwards [64]. Second, job insecurity is a future-focused phenomenon [14]. Job insecurity reflects a forecast about a loss event, which might occur one day in the future [18]. Consequently, employees are 'groping in the dark' as far as their future within the organisation is concerned [64]. Third, job insecurity refers to its involuntary nature; the feeling of powerlessness is also part of many job insecurity definitions. Moreover, job insecurity captures the feeling of helplessness to preserve the desired job continuity [64]. Here it is important to underline that research on job insecurity does not focus on employees who prefer and deliberately choose an uncertain job status while working with a temporary contract [14]. Finally, job insecurity is about the stability and continuity of one's current employment and accordingly differs from employability, as a related construct, which captures an individual's perceived ability to obtain a new job [64]. The current paper treats job insecurity as a global construct comprising a perceived, unwelcome threat to the current job, as suggested in a study of Sverke et al. [19].

As mentioned earlier, job insecurity might generate a vast range of outcomes for individuals and organisations. Seeing that the paper limits its scope only to happiness at work, the next subsection describes the meaning of this construct and reveals the nature of its dimensions, namely job satisfaction, affective organisational commitment, and work engagement. 


\subsection{Happiness at Work}

The debates surrounding the questions-Can people be happy? How can they reach happiness?-have their roots in ancient times, having been particularly influenced by the works of Aristotle [68]. It seems that being happy is of capital importance to most people, [24] and, accordingly, happiness has been found to be a highly valued goal in most societies [69]. According to Diener et al. [70], happiness is a broad phenomenon that includes people's emotional responses, domain satisfactions, and global judgments of life satisfaction. In general, happiness refers to people's evaluations of their lives and the evaluations are both affective and cognitive [69]. Actually, people are happy when they "feel many pleasant and few unpleasant emotions, when they are engaged in interesting activities, when they experience many pleasures and few pains, and when they are satisfied with their lives" [69] (p. 34).

Turning to the organisational setting, it should be admitted that happiness at work is not a term that has been extensively used in academic research on employee experiences in organisations [24]. This does not mean that no interest in happiness at work exists; just for many years, separate constructs have been studied that appear to have a considerable overlap with the broad concept of happiness [24]. Nonetheless, lately the situation has been changing, as a growing number of studies have started introducing the construct of happiness at work, treating it as a higher-order construct [20,21,23,24,71-75].

According to Fisher [24], happiness at work implies happy feelings towards the job itself, the job's characteristics, and the organisation as a whole. According to this definition, the conceptualisation of happiness at work should consider evaluative judgments of job characteristics, such as salary, supervision, and career opportunities, affective implication and feelings at work, and feelings of belonging to the organisation. These three aspects could be captured using job satisfaction, affective organisational commitment, and work engagement [24]. Actually, the current paper follows the earlier conceptualisation of happiness at work, arguing that happiness at work integrates and clarifies its three dimensions, but as a higher-order construct and a general attitude measure it enables compatibility when seeking to link job insecurity and employee attitudes.

Job satisfaction. Usually, job satisfaction is considered to be a major concept in organisations [76]. It has traditionally been linked with employee performance, since an organisation with more satisfied employees tends to be more effective and productive [77]. As underlined by Locke [78], job satisfaction is "a positive emotional state resulting from the appraisal of one's job or job experiences" (p. 229). Warr [79] argues that job satisfaction is the extent to which people are satisfied with their work. Therefore, job satisfaction refers to judgements about the work itself, as a result of the job's characteristics (gladness, joy) [21]. Actually, job satisfaction is the affective orientation that an employee has towards his/her work [80]. It is possible to explore a global feeling about the job or feeling about its different aspects. The global approach is used when the overall attitude is of interest while the facet approach is used to explore which parts of the job produce satisfaction [81].

Affective organisational commitment. Organisational commitment is generally defined as an individual's attitude towards an organisation consisting of three aspects: a strong belief in, and acceptance of, the organisation's goals and values; a willingness to exert considerable effort on behalf of the organisation; and a strong desire to maintain membership of the organisation [82-84]. From employee perspective, commitment is a psychological state that has direct implications on the continuing membership of that particular employee within the current organisation [83].

According to Allen and Meyer [83], organisational commitment is a multi-dimensional construct with three components: affective, continuance, and normative commitment. Although the link between employee and organisation that decreases the likelihood of turnover is common to all these components, the nature of that link radically differs [83]. Employees with strong affective commitment remain because they want to, employees with strong continuance commitment because they need to, and finally, employees with strong normative commitment because they ought to do so [83]. 
For the purposes of this paper, the focus is placed only on affective commitment, which refers to an emotional attachment between the employee and the organisation, in the sense that the committed employees identify with and enjoy belonging to the particular organisation $[83,84]$. Affective commitment refers to employees' emotional attachment to their organisations and sense of inclusion in their organisations' social and psychological communities [66].

Work engagement. In recent years, work engagement has attracted considerable interest in the popular press, as well as among consulting firms and scholars $[85,86]$ given its association with high levels of employee creativity, task performance, organisational citizenship behaviour, and client satisfaction [87-90].

The definition and meaning of employee engagement have been problematic from the beginning [86]. Within the academic perspective, four main approaches define the existing state of employee engagement (for the overview see Shuck [91]); however, two of them are most influential, namely Kahn's [92] need-satisfying approach and the burnout-antithesis approach of Maslach et al. [93].

The first definition to appear in the academic literature was introduced by Kahn [92] arguing that personal engagement is "the harnessing of organisation members' selves to their work roles; in engagement, people employ and express themselves physically, cognitively, and emotionally during role performances" (p. 694). Thus, engagement is the "simultaneous employment and expression of a person's 'preferred self' in task behaviours that promote connections to work and to others, personal presence (physical, cognitive, and emotional), and active, full role performance" [92] (p. 700). Engagement is likely to occur when three conditions, namely, meaningfulness, safety, and availability, are displayed. Meaningfulness refers to "sense of return on investments of self in role performance" (p. 705); safety implies an ability to show one's self "without fear or negative consequences to self-image, status, or career" (p. 705); while availability represents a "sense of possessing the physical, emotional, and psychological resources necessary for investing it" [92] (p. 705) in various activities.

The second influential definition of engagement has its basis in the literature on job burnout and defines engagement as the opposite or positive antithesis of burnout [93,94]. At the beginning of the 21st century, the burnout literature was dominated by two characteristics: first, burnout was closely linked with professions where employees were responsible for interacting with people in stressful situations, and second, it was understood as the antithesis to work engagement [91,93]. Further, arguing that engagement and burnout were independent states while still supporting the notion that engagement was the opposite of burnout, Schaufeli et al. [95] defined work engagement "as a positive, fulfilling, work-related state of mind that is characterised by vigour, dedication, and absorption" (p. 74). Based on the latter definition, in engagement, fulfilment exists in contrast to the voids of life that leave people feeling empty, as in burnout [87]. Moreover, engagement refers to a more persistent and pervasive affective cognitive state that is not focused on any particular object, event, individual, or behaviour [95]. Thus, engagement is conceptualised as a three-dimensional construct. Vigour is defined by high levels of energy and mental resilience while working, willingness to invest effort in one's work, and persistence even when faced with difficulties. Dedication is characterised by the sense of enthusiasm, inspiration, pride, significance, and challenge. Absorption refers to being fully concentrated and deeply engrossed in one's work, where time passes quickly and one has difficulties with detaching oneself from work [95]. This paper follows the work engagement definition provided by Schaufeli et al. [95]. Summing up, engaged employees are enthusiastic about their work, have high levels of energy and, finally, they are often fully immersed in their work so that time flies [96].

\subsection{Job Insecurity and Happiness at Work}

Drawing upon previous literature, it seems that stress theory [31], COR theory [32], and psychological contract theory $[33,97]$ are the main theoretical approaches used to 
explain the relationship between job insecurity and dimensions of happiness at work. The current paper shortly addresses all of them.

In line with the stress theory, researchers who argue that job insecurity has a negative effect on attitudinal outcomes consider job insecurity a hindrance stressor that triggers undesirable strain reactions $[31,98]$. A hindrance stressor is defined as excessive or undesirable work-related demand or a circumstance that interferes with or hinders an individual's ability to achieve goals [99]. As job insecurity reflects uncontrollability [64], one way of dealing with such a situation is psychological withdrawal, referring to psychological increasing of the distance between oneself and the job and the organisation, seeking to reduce the negative impact of a possible job loss [100]. As a result, lower affective organisational commitment, job satisfaction, and work engagement are considered to be psychological coping reactions frequently associated with job insecurity.

The conservation of resources (COR) theory [32] also provides guidance to develop the linkage between job insecurity and employee attitudinal outcomes. According to this theory, resources are defined as "those objects, personal characteristics, conditions, or energies that are valued by the individual or that serve as a means for attainment of these objects, personal characteristics, conditions, or energies" [32] (p. 516). In such a case, individuals strive to acquire and preserve their limited resources [101]. Meanwhile, the situation described as the presence of excessive job demands and/or inadequate resources within a work domain can engender undesirable outcomes [102]. Accordingly, when feeling insecure about their jobs, employees will try to limit the loss of job resources, for instance, by putting forth less effort, which in turn can lead to lower levels of job satisfaction [103].

From the psychological contract theory point of view, psychological contract refers to the set of explicitly or implicitly given promises, including duties and entitlements between employer and employee, as perceived by the employee [104]. In line with the notion that the psychological contract is likely to include job security [105], employees may perceive job insecurity as a breach of the psychological contract with their employer [103]. As a result of such a breach, employees contribute less to the organisations in terms of work engagement or other attitudinal outcomes [10].

Turning to empirical evidence regarding the linkage between job insecurity and job satisfaction, studies mostly supported the negative relationship, except in the cases of no statistical significance [17]. Ashford et al. [106] showed that employees who felt insecure about their future employment were more dissatisfied with their jobs compared to those who perceived their future job situation as more secure. De Cuyper et al. [107] found, based on a study of workers from 23 Belgian organisations, that job insecurity related negatively to job satisfaction in case of permanent workers, but that was not the case with fixed-term contract workers for whom the relationships were non-significant. Several years ago, both Callea et al. [108] and Chirumbolo et al. [109] surveyed different samples of Italian workers finding significant negative effects on job satisfaction. More recently, the study of Emanuel et al. [110] on job insecurity showed its significant negative association with job satisfaction. Moreover, three meta-analyses, too, demonstrated a negative relation between job insecurity and job satisfaction $[9,12,13]$.

Turning to affective organisational commitment, the findings are similar to the case of job insecurity, referring to the negative association between the two constructs. For instance, Chirumbolo et al. [109] found that job insecurity among Italian workers was negatively related to affective organisational commitment. Based on a study of 291 white-collar employees working in various organisations in Lithuania, Lazauskaite-Zabielske et al. [28] reported that qualitative job insecurity was negatively related to affective organisational commitment. Three meta-analyses by Cheng and Chan [12], Sverke et al. [13], and Jiang and Lavaysse [9] confirmed a negative relationship between job insecurity and organisational commitment, including its affective aspect.

Regarding work engagement, empirical evidence claims a negative linkage with job insecurity. De Cuyper et al. [111] demonstrated, based on results from a sample of 559 respondents from divisions of seven Belgian organisations, that job insecurity was 
related to reduced engagement. After analysing data from employees in Korea, Park and Ono [112] found that job insecurity negatively predicted work engagement. A metaanalysis by Jiang and Lavaysse [9] confirmed a negative relationship between job insecurity and work engagement.

To the best knowledge of authors of the current paper, no empirical studies were previously conducted on the relationship between happiness at work as a higher-order construct and job insecurity. However, the theoretical approaches (stress theory, COR theory, psychological contract theory) speak for the negative nature of the linkage.

Based on theoretical reasoning and the dominating previous empirical findings from primary studies and meta-analyses, the paper hypothesises the following:

Hypothesis 1 (H1). Job insecurity will be negatively related to job satisfaction.

Hypothesis 2 (H2). Job insecurity will be negatively related to affective organisational commitment.

Hypothesis 3 (H3). Job insecurity will be negatively related to work engagement.

Hypothesis 4 (H4). Job insecurity will be negatively related to happiness at work.

The theoretical model is provided below (Figure 1).

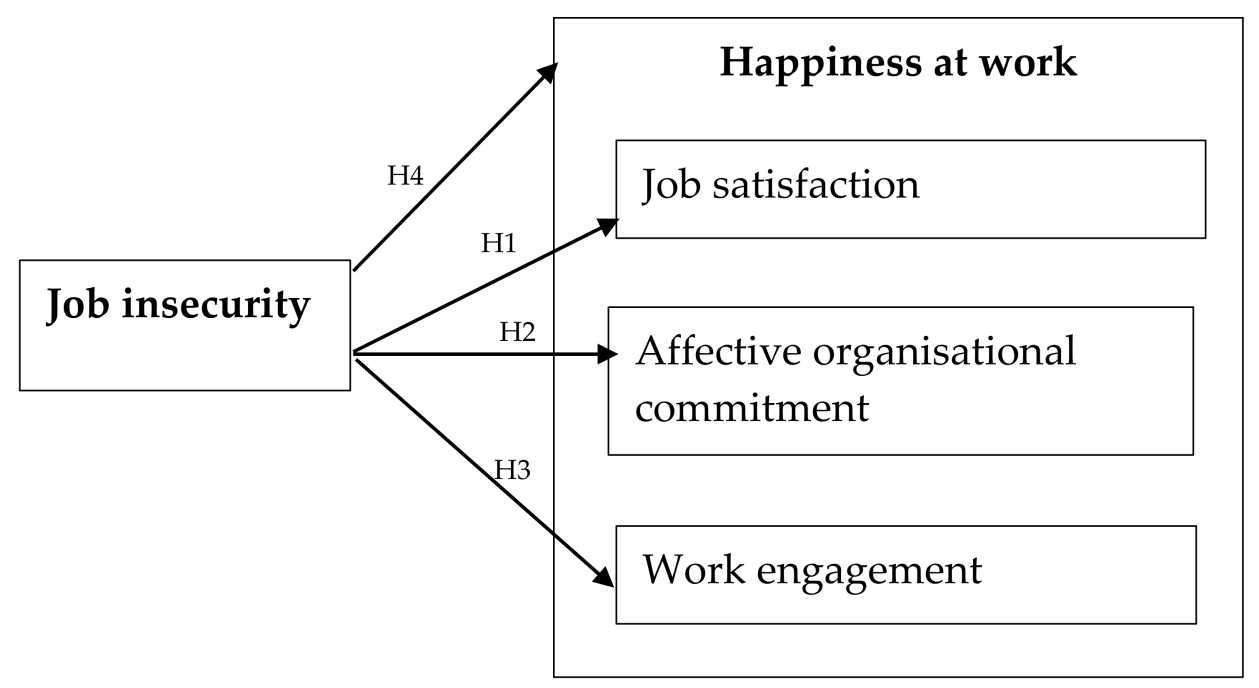

Figure 1. Theoretical model (compiled by the authors).

\section{Methodology}

\subsection{Sample and Data Collection}

The respondents chosen to gather the data and test the hypotheses were operators of robotised furniture production lines in Lithuania. Five furniture companies were surveyed in 2020. The research was based on the criterion of convenience in order to obtain the data from the respondents who were easier to reach; however, certain inclusion criteria were applied: (1) working in furniture manufacturing industry; (2) working on robotised production lines. Paper questionnaires were distributed to the employees. Data collection took approximately 1 month in October-November 2020. At the end of the research, 350 questionnaires were collected. According to the numbers of the employees working in the Lithuanian furniture sector $(27,724)$, such an amount of responses reflected an acceptable bias of $5.4 \%$, which indicated the reliability of the data. Concerning the respondent profile, data about gender, age, education, and time worked for the organisation were collected. The sociodemographic characteristics of the sample are reported in Table 2. 
Table 2. Respondents' profile.

\begin{tabular}{cc}
\hline Furniture industry & Number \\
Working on robotised production line & 350 \\
Gender & 350 \\
Male & 215 \\
Female & 135 \\
\hline Age & 17 \\
\hline Generation Z (date of birth 2002 and later) & 176 \\
Generation Y (date of birth 1981-2001) & 123 \\
Generation X (born in 1965-1980) & 34 \\
Baby boom generation (born in 1946-1964) & 145 \\
Education & 205 \\
Higher education & \\
Non-degree & 15 \\
\hline Under 1 year & 74 \\
1-3 years & 134 \\
3-5 years & 104 \\
5-10 years & 23 \\
\hline 10 years and more
\end{tabular}

\subsection{Measures}

Job insecurity was measured using a four-item scale developed by De Witte [113]. Sample items are: "I feel insecure about the future of my job" and "I am sure I can keep my job" (reverse-coded). Cronbach's alpha was 0.675.

The measurement of job satisfaction was based on a single item ("Taking everything into account, I am satisfied with my job"), provided in the research of Steijn and Van der Voet [114]. Earlier studies have shown that measuring job satisfaction by a single item is easier and may contain more face validity than multiple-item measures [115].

Affective organisational commitment was measured by three items used in the research of Moideenkutty et al. [116]. Originally, the items were based on the affective commitment scale developed by Allen and Meyer [83]. An example of an item is "I really feel as if this organisation's problems are my own". Cronbach's alpha was 0.707.

Work engagement was measured using an ultra-short measure (the UWES-3, threeitem scale) developed by Schaufeli et al. [117]. The items are the following: "At my work, I feel bursting with energy" (vigour); "I am enthusiastic about my job" (dedication); and "I am immersed in my work" (absorption). Cronbach's alpha was 0.689.

Response options ranged from 1, "strongly disagree", to 5, "strongly agree".

Happiness at work was measured as a higher-order construct, which consists of job satisfaction, affective organisational commitment, and work engagement. Cronbach's alpha was 0.833 .

All items are provided in Appendix A.

\subsection{Data Analysis}

Statistical analysis was performed using the statistical package IBM SPSS Statistics Standard v.23. Respondents' demographics were summarised using descriptive statistics. As the data had a skewed distribution, the Spearman's coefficient was used as a measure of bivariate correlations between the main variables of the study. Logistic regression analyses were conducted to examine the relationships between happiness at work (including its dimensions) and job insecurity. Multiple logistic regression analyses using an enter method were conducted. Models were adjusted for personal factors (gender, age, level of education, and years worked for the organisation). Results were considered statistically significant at a $5 \%(p<0.05)$ significance level. Scores for all scales used were calculated. 


\section{Results}

The means, standard deviations and correlation matrix are provided in Table 3.

Table 3. Mean, standard deviation and Spearman correlations.

\begin{tabular}{|c|c|c|c|c|c|c|c|c|c|c|c|}
\hline Title 1 & Mean & SD & 1 & 2 & 3 & 4 & 5 & 6 & 7 & 8 & 9 \\
\hline 1. Gender & 1.39 & 0.49 & & & & & & & & & \\
\hline 2. Age & 2.50 & 0.74 & 0.056 & & & & & & & & \\
\hline $\begin{array}{l}\text { 3. Education } \\
\text { 4. Time }\end{array}$ & 1.59 & 0.49 & 0.035 & $-0.122 *$ & & & & & & & \\
\hline $\begin{array}{l}\text { worked for the } \\
\text { organisation }\end{array}$ & 3.13 & 0.96 & -0.046 & $-0.370^{* *}$ & -0.077 & & & & & & \\
\hline $\begin{array}{l}\text { 5. Job } \\
\text { insecurity }\end{array}$ & 2.76 & 0.65 & $-0.168^{* *}$ & $-0.174^{* *}$ & 0.017 & 0.014 & & & & & \\
\hline $\begin{array}{l}\text { 6. Happiness at } \\
\text { work }\end{array}$ & 3.59 & 0.57 & 0.163 ** & 0.134 * & 0.000 & -0.044 & $-0.294^{* *}$ & & & & \\
\hline $\begin{array}{l}\text { 7. Job } \\
\text { satisfaction } \\
\text { 8. Affective }\end{array}$ & 3.78 & 0.71 & $0.164^{* *}$ & 0.064 & 0.014 & -0.007 & $-0.213^{* *}$ & $0.769 * *$ & & & \\
\hline $\begin{array}{l}\text { organisational } \\
\text { commitment }\end{array}$ & 3.33 & 0.72 & 0.099 & 0.090 & -0.001 & -0.064 & $-0.239 * *$ & $0.828^{* *}$ & $0.439 * *$ & & \\
\hline $\begin{array}{c}\text { 9. Work } \\
\text { engagement }\end{array}$ & 3.65 & 0.62 & 0.135 * & 0.130 * & 0.018 & -0.028 & $-0.254^{* *}$ & $0.849 * *$ & $0.541^{* *}$ & $0.623^{* *}$ & \\
\hline
\end{tabular}

Notes: $\mathrm{n}=350 ;{ }^{*} p<0.05 ; * * p<0.01$; SPSS 23 was used to calculate the means and standard deviations; reported means of latent variables were zero in cross-sectional analyses. Correlations between variables such as job insecurity were measured with one construct only (i.e., not a latent variable).

As is seen from Table 3, the mean of ratings of job insecurity perceived by the respondents was 2.76. Meanwhile, happiness at work (mean 3.59), job satisfaction (mean 3.78), affective organisational commitment (mean 3.33), and work engagement (mean 3.65) were evaluated higher.

As can be further deduced from Table 3, a negative correlation between job insecurity and job satisfaction was revealed $(-0.213, p<0.01)$. The same situation was observed with respect to other two dimensions of happiness at work, seeing that negative correlations between job insecurity and affective organisational commitment $(-0.239, p<0.01)$ and between job insecurity and work engagement $(-0.254, p<0.01)$ were found. Finally, according to the results, job insecurity negatively correlated with happiness at work $(-0.294, p<0.01)$.

To test the study hypotheses, multiple regression analyses were conducted (Table 4). The results are discussed further.

Table 4. Multiple regression results.

\begin{tabular}{|c|c|c|c|c|c|}
\hline \multirow{2}{*}{ Independent Variables } & \multicolumn{5}{|c|}{ Dependent Variable: (Standardised $\beta$ ) } \\
\hline & Job Insecurity & Job Insecurity H1 & Job Insecurity $\mathrm{H} 2$ & Job Insecurity H3 & Job Insecurity $\mathrm{H} 4$ \\
\hline \multicolumn{6}{|l|}{ Control variables } \\
\hline Gender & $-0.162 *$ & $-0.122 *$ & $-0.134^{* * *}$ & $-0.127^{* *}$ & $-0.114^{* *}$ \\
\hline Age & $-0.161 *$ & $-0.153 * *$ & $-0.142 * *$ & $-0.135 * *$ & $-0.135^{* *}$ \\
\hline Education & 0.007 & 0.010 & 0.011 & 0.019 & 0.016 \\
\hline $\begin{array}{c}\text { Time worked for the } \\
\text { organisation }\end{array}$ & -0.041 & -0.046 & -0.044 & -0.049 & -0.048 \\
\hline \multicolumn{6}{|l|}{ Sub-constructs } \\
\hline Job satisfaction & & $-0.249 * * *$ & & & \\
\hline $\begin{array}{l}\text { Affective organisational } \\
\text { commitment }\end{array}$ & & & $-0.244^{* * *}$ & & \\
\hline Work engagement & & & & $-0.270^{* * *}$ & \\
\hline \multicolumn{6}{|l|}{ Construct } \\
\hline Happiness at work & & & & & $-0.303^{* * *}$ \\
\hline $\begin{array}{ll}11 & \mathrm{R} 2\end{array}$ & 0.052 & 0.112 & 0.110 & 0.122 & 0.141 \\
\hline Total F & $4.686^{* * *}$ & $8.646^{* * *}$ & $8.475^{* * *}$ & $9.567^{* * *}$ & $11.291^{* * *}$ \\
\hline Adjusted R2 & 0.041 & 0.099 & 0.097 & 0.109 & 0.128 \\
\hline
\end{tabular}


Hypothesis 1 proposed a negative relationship between job insecurity and job satisfaction. As it is seen from Table 4 , job insecurity caused a decline in job satisfaction $(-0.249$, $p<0.001)$. Thus, Hypothesis 1 was confirmed.

Regarding Hypothesis 2, a negative association between job insecurity and affective organisational commitment was predicted. This hypothesis was also confirmed, since from Table 4 it is seen that job insecurity lowered the affective commitment of employees $(-0.244, p<0.001)$.

As illustrated in Table 4, job insecurity exerted a negative effect on work engagement $(-0.270, p<0.001)$, thus supporting Hypothesis 3 .

Finally, Hypothesis 4 suggested a negative relationship between job insecurity and happiness at work. The results showed a negative interaction between the two constructs $(-0.303, p<0.001)$. This finding supported the view that job insecurity was a work stressor that interfered with employees being happy.

\section{Discussion}

The paper was structured around the research in the field of job insecurity following the view that work is of crucial importance for individuals [14,64]. In general, work allows for fulfilment of various fundamental human needs [118]. The prospect of losing one's employment means the frustration of some fundamental human needs [14,64]. Actually, "fearing that one will lose one's job seems as aggravating as to actually be unemployed" [64] (p. 3). Consequently, this underscores the importance of job insecurity research.

Further, the results are discussed and interpreted in the light of previous empirical findings and theoretical frameworks, namely following the hindrance stressor dimension of the stress model, conservation of resources theory, and psychological contract theory. Next, practical implications for the practitioners are provided. Finally, the limitations are underlined and some avenues for further research are provided.

\subsection{Theoretical Implications}

First of all, it is relevant to mention that the current paper deals with job insecurity in a specific setting. More precisely, the focus is placed on robotised production line operators working in highly robotised furniture industry in Lithuania. Given this focus, the paper expands the field of knowledge on job insecurity, supporting the notion that context matters [26], while using samples from different industries and countries might reveal different employee experiences and responses to job insecurity [8].

The widespread introduction of robots, particularly in manufacturing, reflects both high expectations and deep concerns [119]. The concerns might be reflected by employees in "the subjectively perceived and undesired possibility to lose the present job in the future, as well as the fear or worries related to this possibility of job loss" [14] (p. 365). Hence, employees experience job insecurity, which is situated between employment and unemployment [64]. One of the first objectives of the current paper was to measure the job insecurity of particular respondents from the furniture industry. The findings demonstrated a level of job insecurity that was not particularly high (mean 2.76) and allowed for suggesting that workers did not perceive the threat of losing the current job in the future as high [67]. One viable explanation is that employees have been already working with robots, and they treat themselves as skilled enough to be a critical and valuable part of "robot society". Given the fact that the majority of previous studies were conducted in the service sector [120] or dealt with white-collar workers [15], it is quite difficult to provide comparisons. However, having country in mind, it is possible to compare the results with earlier findings in Lithuania, where a study of 291 white-collar employees working in various organisations revealed similar but lower ratings of job insecurity reflected in the mean of 2.52 on a scale from 1 to 5 [28]. When it comes to studies in other countries and industries, the experience of employee job insecurity varies from really low to higher. For instance, in the case of a sample consisting of employees from a large Sweden manufacturing company that specialises in household appliances and 
forestry and farming equipment, employees evaluated their job insecurity with a mean of 1.73 on a scale from 1 to 5 [10]. Meanwhile, Karatepe et al. [101] found that employees working in the hotel in China experienced job insecurity rated by a mean of 2.67 (on a scale from 1 to 5). According to the distinctions in perceptions, the current paper belongs to the stream of studies arguing for more focus on particular industries when examining job insecurity.

When it comes to happiness at work, the findings demonstrated that operators were quite happy (a mean of 3.59 on the scale from 1 to 5 ). As the findings are similar to those found in other sectors (for instance health care sector) [20,21], it is possible to claim that sharing space with robots might not fundamentally impact the feeling and the state of being happy at work.

Going further, the paper linked job insecurity to happiness at work and its dimensions. As predicted, the findings revealed that job insecurity was harmful for employees in terms of previously mentioned attitudinal outcomes. Thus, the current paper is consistent with the majority of previous studies showing that job insecurity was perceived as a work stressor $[17,100]$, which, in comparison to other work-related stressors, was scored "among the most prominent psychological risks at the workplace, alongside aspects such as workload, lack of control, role ambiguity, role conflicts" [17] (p. 19).

Turning to the linkage between job insecurity and job satisfaction, the current study replicated the previous empirical findings on negative effect [107,121,122]. Drawing upon the results, job insecurity impairs the positive feeling of employees about the job, seeing that job satisfaction concerns the way an employee feels about the job, generally, in the sense of how positive the feeling is $[123,124]$. The findings can be interpreted based on several theories. Here, the attention was drawn only to the psychological contract theory [33]. Psychological contract captures the employees' expectations of reciprocal obligations (i.e., what employees expect to do for their employer, what demands are placed by the organisation on employees) and entitlements (i.e., what employees expect to receive from their employer in return, what are the specific rewards) $[10,125]$. Accordingly, the idea of balance is fundamental, implying that a perceived imbalance between efforts and rewards results in the perception of a breach of the contract [125]. In Lithuania, as in other Western Europe countries, individuals consider secure employment as part of a psychological contract. Job insecurity constitutes a violation of employer's obligation and has been described as a source of breach of the relational psychological contract $[10,14]$. Feeling that the promises are broken may lead to less satisfaction with the job.

As predicted, a negative relationship between job insecurity and affective organisational commitment was found. More specifically, the perceived threat of losing the job appeared to be related to lower levels of employees' emotional attachment to, involvement in, and identification with their employers [116]. Actually, lower emotional attachment to organisations was previously revealed by separate studies and supported by metaanalysis [12,13]. Nonetheless, the current paper complements the prior research, showing that the negative effect between the two constructs unfolds in the specific setting of robotised production line operators, with actual changes in the production process due to the introduction of robots. Although various theories could be invoked while explaining why job insecurity reduces affective organisational commitment, the paper interprets this relationship from the COR perspective. According to the COR theory, individuals strive to retain, protect, and accumulate resources that are valuable to them when they perceive a potential or actual loss of them [126]. As work and employment are both valuable conditions for individuals [64], job insecurity entails an anticipated loss of this condition leading to a situation where employees tend to conserve or redirect personal resources to prevent further losses [66]. In other words, when employees are threatened with the loss of desired job, they anticipate a poorer relationship with their organisations in the future and display lower emotional attachment to an organisation.

As regards work engagement, the findings supported the hypothesis regarding the detrimental effect of job insecurity on work engagement. Such findings are in line with 
previous studies $[9,127]$, leading to the notion that job insecurity results in lower levels of energy and mental resilience of employees while working, weaker involvement in work, and lower experience of the sense of significance, enthusiasm, and challenge, and, finally, lower concentration and engrossment in work [86]. Such an effect might also be explained by the stress theory [31]. Coping with job insecurity as a hindrance stressor requires psychological withdrawal from the employee [100], which might manifest in lower work engagement.

Turning to happiness at work, the findings revealed that job insecurity served as a determinant, causing the employees to feel less happy at work. In this paper, happiness at work was treated as a higher-order construct, which refers to happy feelings towards the job itself, the job's characteristics, and the organisation as a whole [24]. The relevance of happiness at work is somehow based on the "happy-productive worker" hypothesis, which, according to Fisher [24], is much truer than previously thought. Dissatisfied, less committed or less engaged employees are less dedicated to the organisation and its goals and tend to ruin its social atmosphere [64]. Happiness at work elicits significant consequences for both employers and employees as it is related to task and contextual performance, employee retention, customer satisfaction, productivity, and profitability [24,124]. However, happiness at work might be at risk due to the feeling that the job is at risk. As job insecurity is considered a job stressor and a potential cause of breaking psychological contract and losing valuable resources, being happy at work during an unpredictable period in a "robot society" is more challenging than ever before.

\subsection{Practical Implications}

Besides theoretical implications, this paper has some managerial implications for practitioners. Based on the finding that job insecurity reduces happiness at work, including job satisfaction, affective organisational commitment, and work engagement, organisations aiming for happy employees need to decrease their perceptions of job insecurity. However, this is a challenging task due to the nature of job insecurity and its inevitability in today's organisations, especially with regards to robotisation, which leads to the situation where "most people in the future will not need to work, at least in the ways in which we continue to think about work/human labour" [4] p. 127). Nonetheless, several aspects might be taken into consideration by practitioners. First, in order to identify increases in job insecurity early on and make it easier to intervene at the right time, employers need to regularly monitor (for instance, by means of questionnaires) human resource management processes, changes, and employee reactions to these changes [103]. Next, job insecurity is problematic as it implies unpredictability and uncontrollability [64]. For employees it is not clear what will happen in the future, especially reading controversial messages regarding the role of robots: will they substitute humans or create more new jobs [6]? Moreover, employees feel a lack of control or powerlessness about technological advancement. Job insecurity could be mitigated only through reduction of unpredictability and uncontrollability $[15,64]$. For this, several ways are proposed, such as communication [128], participation in decision making [129], enhancing employee perception of fairness [28,130], and better-perceived control [67]. Finally, organisations should treat their employees with respect and openness, share the future plans and provide support while employees are coping with work stressors, including the perceived threat of job loss and worries related to the mentioned threat $[15,64,103]$.

\subsection{Limitations}

This research has some limitations that should be acknowledged when interpreting the results. The first concern is about the linking mechanism between job insecurity and happiness at work. Recently, the focus has been increasing on the mechanisms through which this work stressor relates to its outcomes; that is, how job insecurity develops into subsequent consequences through intermediary factors [10]. Although it was outside the scope of the paper to explore possible mediators and moderators that could strengthen or weaken the 
relationship between job insecurity and happiness at work, future research nonetheless needs to consider a potential linking mechanism and to examine the intervening factors.

The second concern relies on the dimensions of happiness at work. Although the vast majority of prior studies captured happiness at work as a three-dimensional construct [20,21], there are more happiness-related constructs [24]. Future research needs to go further while conceptualising happiness at work.

The third concern deals with the sample specifics. The sample consisted of robotised production line operators working in the furniture sector. For this reason, the result could not be generalised to other manufacturing sectors or other industries.

The fourth concern relates to the possibility to explore the generalisability of the results to other cultures and countries. Since the sample was from one country only, it would be interesting to examine whether the job insecurity-happiness at work relationship varies across countries and whether this variation depends on specific country-level characteristics. In this respect, the current research supports the interest and call that was also raised by some earlier studies [31,131].

\section{Conclusions}

The aim of the paper was to explore the relationship between job insecurity and happiness at work, including its three dimensions. More specifically, treating job insecurity as a hindrance stressor and relying on the conservation of resources and psychological contract theories, the paper claimed a negative association between job insecurity and happiness at work, including job satisfaction, affective organisational commitment, and work engagement. In doing this, the current paper expanded the scope of the prior literature while concentrating on the second-order construct (happiness at work) and the way it was influenced by job insecurity. The survey was conducted using a sample, which consisted of robotised production line operators working in the furniture sector, characterised by a specific context due to high pressure for its automation and robotisation. The survey revealed that the respondents did not perceive the threat of losing their current jobs in the future as high. When it comes to happiness at work, the findings demonstrated that the operators were quite happy, felt job satisfaction and affective organisational commitment, and were engaged in work. As predicted, the findings revealed that job insecurity served as a determinant of lower happiness at work and all its dimensions. More specifically, job insecurity caused impaired job satisfaction; consequently, employees had lower positive feelings about the job. Next, as a result of job insecurity, lower levels of emotional attachment to, involvement in, and identification with their employers were observed. Finally, job insecurity caused lower levels of energy and mental resilience for employees while working as well as weaker involvement in work, a lower sense of significance, enthusiasm, and challenge, and lower concentration and engrossment in work. Irrespective of the fact that job insecurity might be one of the stressors inherent to contemporary societies that employees have to "live with", organisations are responsible for helping their employees to cope with job insecurity effectively, seeing that only happy employees are productive workers that lead to sustainable business performance.

Author Contributions: Conceptualization, Ž.S., E.S. and J.R.; methodology, Ž.S., E.S. and J.R; software, Ž.S., E.S. and J.R; validation, Ž.S., E.S. and J.R; formal analysis, Ž.S., E.S. and J.R; data curation, Ž.S., E.S. and J.R; writing—original draft preparation, Ž.S., E.S. and J.R; writing-review and editing, Ž.S., E.S. and J.R; visualization, Ž.S., E.S. and J.R; supervision, Ž.S.; project administration, Ž.S.; funding acquisition, Ž.S. All authors have read and agreed to the published version of the manuscript.

Funding: This research was funded by Kaunas University of Technology, Kaunas, Lithuania, grant number PP59/2014 (INP2020/24) and the APC was funded by Kaunas University of Technology, Kaunas, Lithuania.

Institutional Review Board Statement: Not applicable.

Informed Consent Statement: Not applicable. 
Conflicts of Interest: The authors declare no conflict of interest.

\section{Appendix A. Survey Items}

Job insecurity (De Witte [113]):

1. I feel insecure about the future of my job.

2. I am sure I can keep my job (reverse coded).

3. Chances are, I will soon lose my job.

4. I think, I might lose my job in the near future. Job satisfaction (Steijn and Van der Voet [114]):

1. Taking everything into account, I am satisfied with my job. Affective organisational commitment (Moideenkutty et al. [116].)

1. I really feel as if this organisation's problems are my own.

2. I feel like 'part of the family' at my organisation.

3. I feel a strong sense of belonging to my organisation. Work engagement (Schaufeli et al. [117]):

1. At my work, I feel bursting with energy.

2. I am enthusiastic about my job.

3. I am immersed in my work.

\section{References}

1. van Est, R.; Van Keulen, I.; Kool, L.; van Waes, A.H.M.; Brom, F.; van der Zee, F.; Gijsbers, G.; Korsten, J.; Lintsen, H.; Schot, J. Working on the Robot Society: Visions and Insights from Science Concerning the Relationship between Technology and Employment; Rathenau Instituut: The Hague, The Netherlands, 2015.

2. Moniz, A.; Krings, B.-J. Robots Working with Humans or Humans Working with Robots? Searching for Social Dimensions in New Human-Robot Interaction in Industry. Societies 2016, 6, 23. [CrossRef]

3. Ivanov, S.H. Robonomics-principles, benefits, challenges, solutions. Yearb. Varna Univ. Manag. 2017, 10, $283-293$.

4. Webster, C.; Ivanov, S. Robotics, Artificial Intelligence, and the Evolving Nature of Work. In Digital Transformation in Business and Society; Springer International Publishing: Cham, Switzerland, 2020; pp. 127-143.

5. DeCanio, S.J. Robots and humans-complements or substitutes? J. Macroecon. 2016, 49, 280-291. [CrossRef]

6. Dengler, K.; Matthes, B. The impacts of digital transformation on the labour market: Substitution potentials of occupations in Germany. Technol. Forecast. Soc. Chang. 2018, 137, 304-316. [CrossRef]

7. Zhang, P. Automation, wage inequality and implications of a robot tax. Int. Rev. Econ. Financ. 2019, 59, 500-509. [CrossRef]

8. Lee, C.; Huang, G.-H.; Ashford, S.J. Job Insecurity and the Changing Workplace: Recent Developments and the Future Trends in Job Insecurity Research. Annu. Rev. Organ. Psychol. Organ. Behav. 2018, 5, 335-359. [CrossRef]

9. Jiang, L.; Lavaysse, L.M. Cognitive and Affective Job Insecurity: A Meta-Analysis and a Primary Study. J. Manag. 2018, 44, 2307-2342. [CrossRef]

10. Richter, A.; Näswall, K. Job insecurity and trust: Uncovering a mechanism linking job insecurity to well-being. Work Stress 2019, 33, 22-40. [CrossRef]

11. Nam, T. Technology usage, expected job sustainability, and perceived job insecurity. Technol. Forecast. Soc. Chang. 2019, 138, 155-165. [CrossRef]

12. Cheng, G.H.L.; Chan, D.K.S. Who Suffers More from Job Insecurity? A Meta-Analytic Review. Appl. Psychol. 2008, 57, 272-303. [CrossRef]

13. Sverke, M.; Hellgren, J.; Näswall, K. No security: A meta-analysis and review of job insecurity and its consequences. J. Occup. Health Psychol. 2002, 7, 242-264. [CrossRef]

14. Vander Elst, T.; De Witte, H.; De Cuyper, N. The Job Insecurity Scale: A psychometric evaluation across five European countries. Eur. J. Work Organ. Psychol. 2014, 23, 364-380. [CrossRef]

15. Shin, Y.; Hur, W.M.; Moon, T.W.; Lee, S. A motivational perspective on job insecurity: Relationships between job insecurity, intrinsic motivation, and performance and behavioral outcomes. Int. J. Environ. Res. Public Health 2019, 16. [CrossRef]

16. Sverke, M.; Hellgren, J. The Nature of Job Insecurity: Understanding Employment Uncertainty on the Brink of a New Millennium. Appl. Psychol. 2002, 51, 23-42. [CrossRef]

17. De Witte, H.; Pienaar, J.; De Cuyper, N. Review of 30 Years of Longitudinal Studies on the Association Between Job Insecurity and Health and Well-Being: Is There Causal Evidence? Aust. Psychol. 2016, 51, 18-31. [CrossRef]

18. Shoss, M.K. Job Insecurity: An Integrative Review and Agenda for Future Research. J. Manag. 2017, 43, 1911-1939. [CrossRef] 
19. Sverke, M.; Låstad, L.; Hellgren, J.; Richter, A.; Näswall, K. A Meta-Analysis of Job Insecurity and Employee Performance: Testing Temporal Aspects, Rating Source, Welfare Regime, and Union Density as Moderators. Int. J. Environ. Res. Public Health 2019, 16, 2536. [CrossRef]

20. Salas-Vallina, A.; Alegre, J.; Fernandez, R. Happiness at work and organisational citizenship behaviour. Int. J. Manpow. 2017, 38, 470-488. [CrossRef]

21. Salas-Vallina, A.; López-Cabrales, Á.; Alegre, J.; Fernández, R. On the road to happiness at work (HAW). Pers. Rev. 2017, 46, 314-338. [CrossRef]

22. Bataineh, K.a. Impact of Work-Life Balance, Happiness at Work, on Employee Performance. Int. Bus. Res. 2019, 12, 99. [CrossRef]

23. Moccia, S. Happiness at work. Psychol. Pap. 2016, 37, 143-151.

24. Fisher, C.D. Happiness at Work. Int. J. Manag. Rev. 2010, 12, 384-412. [CrossRef]

25. Shin, Y.; Hur, W.-M. When Do Service Employees Suffer More from Job Insecurity? The Moderating Role of Coworker and Customer Incivility. Int. J. Environ. Res. Public Health 2019, 16, 1298. [CrossRef]

26. Rafiq, M.; Chin, T. Three-Way Interaction Effect of Job Insecurity, Job Embeddedness and Career Stage on Life Satisfaction in a Digital Era. Int. J. Environ. Res. Public Health 2019, 16, 1580. [CrossRef]

27. De Cuyper, N.; Mäkikangas, A.; Kinnunen, U.; Mauno, S.; Witte, H. De Cross-lagged associations between perceived external employability, job insecurity, and exhaustion: Testing gain and loss spirals according to the Conservation of Resources Theory. $J$. Organ. Behav. 2012, 33, 770-788. [CrossRef]

28. Lazauskaite-Zabielske, J.; Urbanaviciute, I.; Bagdziuniene, D. The role of prosocial and intrinsic motivation in employees citizenship behaviour. Balt. J. Manag. 2015, 10, 345-365. [CrossRef]

29. Loi, R.; Lam, L.W.; Chan, K.W. Coping with Job Insecurity: The Role of Procedural Justice, Ethical Leadership and Power Distance Orientation. J. Bus. Ethics 2012, 108, 361-372. [CrossRef]

30. Frey, C.B.; Osborne, M. The Future of Employmen. 2013. Available online: https://www.oxfordmartin.ox.ac.uk/downloads/ academic/The_Future_of_Employment.pdf?link=mktw (accessed on 30 January 2021).

31. Piccoli, B.; Reisel, W.D.; De Witte, H. Understanding the Relationship between Job Insecurity and Performance: Hindrance or Challenge Effect? J. Career Dev. 2019, 1-16. [CrossRef]

32. Hobfoll, S.E. Conservation of resources: A new attempt at conceptualizing stress. Am. Psychol. 1989, 44, 513. [CrossRef]

33. Rousseau, D.M. Psychological Contract: Understanding of Written and Unwritten Agreements; SAGE Publications, Inc.: Newbury Park, CA, USA, 1995.

34. Grant, A.M.; Christianson, M.K.; Price, R.H. Happiness, Health, or Relationships? Managerial Practices and Employee Well-Being Tradeoffs. Acad. Manag. Perspect. 2007, 21, 51-63. [CrossRef]

35. Kiesnere, A.; Baumgartner, R. Sustainability Management in Practice: Organizational Change for Sustainability in Smaller Large-Sized Companies in Austria. Sustainability 2019, 11, 572. [CrossRef]

36. Stahl, G.K.; Brewster, C.J.; Collings, D.G.; Hajro, A. Enhancing the role of human resource management in corporate sustainability and social responsibility: A multi-stakeholder, multidimensional approach to HRM. Hum. Resour. Manag. Rev. 2020, $30,100708$. [CrossRef]

37. European Comission. High-Tech Leadership Skills for Europe-Towards an Agenda for 2020 and Beyond; European Comission: Brussels, Belgium, 2017.

38. Lukšytè, V.; Melnikas, B. Baldu gamyba ir eksporto plètra ekonomikos globalizacijos salygomis. In Proceedings of the 21st Conference for Junior Researchers “Science-Future of Lithuania" Business in XXI Century, Vilnius, Lithuania, 4-5 May 2018; Economics Sustainable Development: Vilnius, Lithuania, 2018; p. 12.

39. Schwab, K. The Fourth Industrial Revolution; World Economic Forum: Geneva, Switzerland, 2017; ISBN 1524758876.

40. European Commission. Knowledge for Policy. Available online: https://ec.europa.eu/knowledge4policy/foresight/topic/ changing-nature-work / AI-and-automation_en (accessed on 23 November 2020).

41. Digybite. Attitudes towards the Impact of Digitisation and Automation on Daily Life. Available online: https:/ / ec.europa.eu/digitalsingle-market/en/news/attitudes-towards-impact-digitisation-and-automation-daily-life (accessed on 23 November 2020).

42. Appleton, E.; Williams, D.J. Industrial Robot Applications; Springer Science \& Business Media: New York, NY, USA, 2012; ISBN 9400931255.

43. International Federation of Robotics. Executive Summary-World Robotics 2019 Industrial Robots; International Federation of Robotics: Frankfurt am Main, Germany, 2019.

44. International Federation of Robotics. Executive Summary World Robotics Report 2020 Industrial Robots; International Federation of Robotics: Frankfurt am Main, Germany, 2020.

45. Liobikienè, G.; Liobikas, J.; Brizga, J.; Juknys, R. Materialistic values impact on pro-environmental behavior: The case of transition country as Lithuania. J. Clean. Prod. 2020, 244, 118859. [CrossRef]

46. Budzinauskas, V. Despite Positive Changes, Social Problems Persist in Lithuania-EU Commission. Available online: https:// www.lrt.lt/en/news-in-english/19/1146277/despite-positive-changes-social-problems-persist-in-lithuania-eu-commission (accessed on 19 January 2021).

47. Vilikanskytė, M. Many jobs in Lithuania Can Be Replaced by Robots—Study. Available online: https://www.lrt.lt/en/news-inenglish/19/1237432/many-jobs-in-lithuania-can-be-replaced-by-robots-study (accessed on 19 January 2021). 
48. Rutkauskaitè, R. SBA Žengia ị Robotu Diegimo Rinka_-Isigijo Bendrovę “Robotex". Available online: https:/ / www.vz.lt/pramone/ 2019/06/17/sba-zengia-i-robotu-diegimo-rinka--isigijo-bendrove-robotex\#ixzz6ec4pOn9r (accessed on 23 November 2020).

49. Markevičienè, E. Pramonei “Lean” Nebeužteks, Reikia Technologijų. Available online: https://www.vz.lt/pramone/2018/06/13 / pramonei-lean-nebeuzteks-reikia-technologiju\#ixzz5INvjRRAh (accessed on 23 November 2020).

50. Statybunaujienos. Lt Pramonès Revoliucija ir Robotai Lietuvos Imonèse: Skelbia Geriausio Sprendimo Paieškas. Available online: http:/ / www.statybunaujienos.lt/naujiena/Pramones-revoliucija-ir-robotai-Lietuvos-imonese-skelbia-geriausiosprendimo-paieskas/12488 (accessed on 23 November 2020).

51. Markevičienè, E. “Pramonè 4.0” Išmokys Darbininkus Valdyti Robotus. Available online: https://www.vz.lt/pramone/2018/02/ 28/pramone-40-ismokys-darbininkus-valdyti-robotus (accessed on 28 November 2020).

52. Linpra Laivus Projektuoja Virtualioje Realybeje, o Stato Robotai. Available online: https:/ /linpra.lt/laivus-projektuoja-virtualiojerealybeje-o-stato-robotai/ (accessed on 28 November 2020).

53. Mrazauskaitè, L. Robotai Nenuslopins Smulkiojo Verslo. Available online: https://linpra.lt/robotai-nenuslopins-smulkiojoverslo/ (accessed on 28 November 2020).

54. European Commission. Coordination of European, National \& Regional Initiatives. Available online: https: / / ec.europa.eu/ digital-single-market/en/coordination-european-national-regional-initiatives (accessed on 28 November 2020).

55. Platform "Pramonè 4.0" Structure. Available online: https:/ / industrie40.1t/ platform-pramone-4-0-structure/ (accessed on 28 November 2020).

56. Lietuvos Statistikos Departamentas. Statistiniu Rodikliu Analizè. Available online: https:/ /osp.stat.gov.lt/statistiniu-rodikliuanalize\#/ (accessed on 28 November 2020).

57. Versli Lietuva. Lietuvos Baldu Gamybos Pramone; Versli Lietuva: Vilnius, Lithuania, 2017.

58. Han, Y. Furniture Report 2020. Available online: https: / www.statista.com/study/55490/furniture/ (accessed on 30 January 2021).

59. OECD. Putting Faces to the Jobs at Risk of Automation; OECD: Paris, France, 2018.

60. Liuima, J. Kurios Lietuvos Pramonès ir Paslaugu Sritys Bus Svarbiausios 2025 Metais? Available online: https:/ /blog.euromonitor. com/kurios-lietuvos-pramones-ir-paslaugu-sritys-bus-svarbiausios-2025-metais/ (accessed on 28 November 2020).

61. Lietuvos Pramonininku Konfederacija. LIETUVOS PRAMONÉS LŪKESČIŲ INDEKSAS. 2019 METU I PUSMETIS; Lietuvos Pramonininku Konfederacija: Vilnius, Lithuania, 2019.

62. Greenhalgh, L.; Rosenblatt, Z. Job Insecurity: Toward Conceptual Clarity. Acad. Manag. Rev. 1984, 9, 438-448. [CrossRef]

63. Rosenblatt, Z.; Ruvio, A. A test of a multidimensional model of job insecurity: The case of Israeli teachers. J. Organ. Behav. 1996, 17, 587-605. [CrossRef]

64. De Witte, H. Job insecurity: Review of the international literature on definitions, prevalence, antecedents and consequences. $S A J$. Ind. Psychol. 2005, 31, 1-6. [CrossRef]

65. Brondino, M.; Bazzoli, A.; Vander Elst, T.; De Witte, H.; Pasini, M. Validation and measurement invariance of the multidimensional qualitative job insecurity scale. Qual. Quant. 2020, 54, 925-942. [CrossRef]

66. Huang, G.; Zhang, Y.; Zhang, X.; Long, L. Job insecurity, commitment and proactivity towards the organization and one's career: Age as a condition. Hum. Resour. Manag. J. 2020, 1748-8583.12322. [CrossRef]

67. Vander Elst, T.; De Cuyper, N.; Baillien, E.; Niesen, W.; De Witte, H. Perceived Control and Psychological Contract Breach as Explanations of the Relationships Between Job Insecurity, Job Strain and Coping Reactions: Towards a Theoretical Integration. Stress Heal. 2016, 32, 100-116. [CrossRef]

68. Tamir, M.; Schwartz, S.H.; Oishi, S.; Kim, M.Y. The secret to happiness: Feeling good or feeling right? J. Exp. Psychol. Gen. 2017, 146, 1448-1459. [CrossRef]

69. Diener, E. Subjective well-being: The science of happiness and a proposal for a national index. Am. Psychol. 2000, 55, 34-43. [CrossRef]

70. Diener, E.; Suh, E.M.; Lucas, R.E.; Smith, H.L. Subjective well-being: Three decades of progress. Psychol. Bull. 1999, 125, 276. [CrossRef]

71. Pryce-Jones, J.; Lindsay, J. What happiness at work is and how to use it. Ind. Commer. Train. 2014, 46, 130-134. [CrossRef]

72. Salas-Vallina, A.; Alegre, J. Happiness at work: Developing a shorter measure. J. Manag. Organ. 2018, 1-21. [CrossRef]

73. De Neve, J.; Ward, G.W. Happiness at Work. SSRN Electron. J. 2017, 7. [CrossRef]

74. Singh, S.; Aggarwal, Y. Happiness at Work Scale: Construction and Psychometric Validation of a Measure Using Mixed Method Approach. J. Happiness Stud. 2018, 19, 1439-1463. [CrossRef]

75. Diaz Pincheira, F.J.; Carrasco Garces, M.E. Effects of organizational climate and psychosocial risks on happiness at work. Contaduría Adm. 2018, 63, 52. [CrossRef]

76. Chiva, R.; Alegre, J. Organizational Learning Capability and Job Satisfaction: An Empirical Assessment in the Ceramic Tile Industry. Br. J. Manag. 2009, 20, 323-340. [CrossRef]

77. Eliyana, A.; Ma'arif, S. Muzakki Job satisfaction and organizational commitment effect in the transformational leadership towards employee performance. Eur. Res. Manag. Bus. Econ. 2019, 25, 144-150. [CrossRef]

78. Locke, E.A. The nature and causes of job satisfaction. In Handbook of Industrial and Organizational Psychology; SAGE Publications, Inc.: Newbury Park, CA, USA, 1976.

79. Warr, P. Psychology at Work; Penguin Books: London, UK, 2002; ISBN 0141932465. 
80. Hoboubi, N.; Choobineh, A.; Kamari Ghanavati, F.; Keshavarzi, S.; Akbar Hosseini, A. The Impact of Job Stress and Job Satisfaction on Workforce Productivity in an Iranian Petrochemical Industry. Saf. Health Work 2017, 8, 67-71. [CrossRef]

81. Lu, H.; Zhao, Y.; While, A. Job satisfaction among hospital nurses: A literature review. Int. J. Nurs. Stud. 2019, 94, 21-31. [CrossRef]

82. Mowday, R.T.; Steers, R.M.; Porter, L.W. The measurement of organizational commitment. J. Vocat. Behav. 1979, 14, $224-247$. [CrossRef]

83. Allen, N.J.; Meyer, J.P. The measurement and antecedents of affective, continuance and normative commitment to the organization. J. Occup. Psychol. 1990, 63, 1-18. [CrossRef]

84. Fernández-Mesa, A.; Llopis, O.; García-Granero, A.; Olmos-Peñuela, J. Enhancing organisational commitment through task significance: The moderating role of openness to experience. Eur. Manag. J. 2020, 38, 602-612. [CrossRef]

85. Cooke, D.K.; Brant, K.K.; Woods, J.M. The Role of Public Service Motivation in Employee Work Engagement: A Test of the Job Demands-Resources Model. Int. J. Public Adm. 2019, 42, 765-775. [CrossRef]

86. Gruman, J.A.; Saks, A.M. Performance management and employee engagement. Hum. Resour. Manag. Rev. 2011, 21, 123-136. [CrossRef]

87. Bakker, A.B.; Demerouti, E.; Sanz-Vergel, A.I. Burnout and Work Engagement: The JD-R Approach. Annu. Rev. Organ. Psychol. Organ. Behav. 2014, 1, 389-411. [CrossRef]

88. Bakker, A.B.; Albrecht, S. Work engagement: Current trends. Career Dev. Int. 2018, 23, 4-11. [CrossRef]

89. Knight, C.; Patterson, M.; Dawson, J. Building work engagement: A systematic review and meta-analysis investigating the effectiveness of work engagement interventions. J. Organ. Behav. 2017, 38, 792-812. [CrossRef]

90. Asif, M.; Qing, M.; Hwang, J.; Shi, H. Ethical Leadership, Affective Commitment, Work Engagement, and Creativity: Testing a Multiple Mediation Approach. Sustainability 2019, 11, 4489. [CrossRef]

91. Shuck, B. Integrative Literature Review: Four Emerging Perspectives of Employee Engagement: An Integrative Literature Review. Hum. Resour. Dev. Rev. 2011, 10, 304-328. [CrossRef]

92. Kahn, W.A. Psychological Conditions of Personal Engagement and Disengagement at Work. Acad. Manag. J. 1990, 33, 692-724. [CrossRef]

93. Maslach, C.; Schaufeli, W.B.; Leiter, M.P. Job Burnout. Annu. Rev. Psychol. 2001, 52, 397-422. [CrossRef] [PubMed]

94. Maslach, C.; Leiter, M.P. Early predictors of job burnout and engagement. J. Appl. Psychol. 2008, 93, 498-512. [CrossRef] [PubMed]

95. Schaufeli, W.B.; Salanova, M.; González-Romá, V.; Bakker, A.B. The measurement of engagement and burnout: A two sample confirmatory factor analytic approach. J. Happiness Stud. 2002, 3, 71-92. [CrossRef]

96. Bakker, A.B.; Demerouti, E. Towards a model of work engagement. Career Dev. Int. 2008, 13, 209-223. [CrossRef]

97. Blau, P.M. Justice in Social Exchange. Sociol. Inq. 1964, 34, 193-206. [CrossRef]

98. Staufenbiel, T.; König, C.J. A model for the effects of job insecurity on performance, turnover intention, and absenteeism. J. Occup. Organ. Psychol. 2010, 83, 101-117. [CrossRef]

99. Cavanaugh, M.A.; Boswell, W.R.; Roehling, M.V.; Boudreau, J.W. An empirical examination of self-reported work stress among U.S. managers. J. Appl. Psychol. 2000, 85, 65-74. [CrossRef]

100. Piccoli, B.; De Witte, H.; Reisel, W.D. Job insecurity and discretionary behaviors: Social exchange perspective versus group value model. Scand. J. Psychol. 2017, 58, 69-79. [CrossRef]

101. Karatepe, O.M.; Rezapouraghdam, H.; Hassannia, R. Job insecurity, work engagement and their effects on hotel employees' non-green and nonattendance behaviors. Int. J. Hosp. Manag. 2020, 87, 102472. [CrossRef]

102. Shaffer, M.A.; Harrison, D.A.; Gilley, K.M.; Luk, D.M. Struggling for balance amid turbulence on international assignments: Work-family conflict, support and commitment. J. Manag. 2001, 27, 99-121. [CrossRef]

103. Schreurs, B.H.J.; Hetty van Emmerik, I.; Günter, H.; Germeys, F. A weekly diary study on the buffering role of social support in the relationship between job insecurity and employee performance. Hum. Resour. Manag. 2012, 51, 259-279. [CrossRef]

104. Conway, N.; Briner, R.B. Understanding Psychological Contracts at Work: A Critical Evaluation of Theory and Research; Oxford University Press: Oxford, UK, 2005; ISBN 0199280649.

105. De Cuyper, N.; De Witte, H. Job insecurity in temporary versus permanent workers: Associations with attitudes, well-being, and behaviour. Work Stress 2007, 21, 65-84. [CrossRef]

106. Ashford, S.J.; Lee, C.; Bobko, P. Content, Cause, and Consequences of Job Insecurity: A Theory-Based Measure and Substantive Test. Acad. Manag. J. 1989, 32, 803-829. [CrossRef]

107. De Cuyper, N.; Notelaers, G.; De Witte, H. Job insecurity and employability in fixed-term contractors, agency workers, and permanent workers: Associations with job satisfaction and affective organizational commitment. J. Occup. Health Psychol. 2009, 14, 193-205. [CrossRef] [PubMed]

108. Callea, A.; Lo Presti, A.; Mauno, S.; Urbini, F. The associations of quantitative/qualitative job insecurity and well-being: The role of self-esteem. Int. J. Stress Manag. 2019, 26, 46-56. [CrossRef]

109. Chirumbolo, A.; Urbini, F.; Callea, A.; Lo Presti, A.; Talamo, A. Occupations at Risk and Organizational Well-Being: An Empirical Test of a Job Insecurity Integrated Model. Front. Psychol. 2017, 8, 2084. [CrossRef]

110. Emanuel, F.; Molino, M.; Presti, A.L.; Spagnoli, P.; Ghislieri, C. A Crossover Study From a Gender Perspective: The Relationship Between Job Insecurity, Job Satisfaction, and Partners' Family Life Satisfaction. Front. Psychol. 2018, 9, 1481. [CrossRef] 
111. De Cuyper, N.; Bernhard-Oettel, C.; Berntson, E.; De Witte, H.; Alarco, B. Employability and Employees' Well-Being: Mediation by Job Insecurity. Appl. Psychol. 2008, 57, 488-509. [CrossRef]

112. Park, J.H.; Ono, M. Effects of workplace bullying on work engagement and health: The mediating role of job insecurity. Int. J. Hum. Resour. Manag. 2017, 28, 3202-3225. [CrossRef]

113. De Witte, H. Arbeidsethos en jobonzekerheid: Meting en gevolgen voor welzijn, tevredenheid en inzet op het werk (Work ethic and job insecurity: Assessment and consequences for well-being, satisfaction and performance at work). In Van Groep naar Gemeenschap (From Group to Community); Bouwen, R., de Witte, K., de Witte, H., Taillieu, T., Eds.; Garant: Leuven, Belgium, 2000; pp. 325-350. ISBN 9044110314.

114. Steijn, B.; van der Voet, J. Relational job characteristics and job satisfaction of public sector employees: When prosocial motivation and red tape collide. Public Adm. 2019, 97, 64-80. [CrossRef]

115. Nagy, M.S. Using a single-item approach to measure facet job satisfaction. J. Occup. Organ. Psychol. 2002, 75, 77-86. [CrossRef]

116. Moideenkutty, U.; Blau, G.; Kumar, R.; Nalakath, A. Perceived Organisational Support as a Mediator of the Relationship of Perceived Situational Factors to Affective Organisational Commitment. Appl. Psychol. 2001, 50, 615-634. [CrossRef]

117. Schaufeli, W.B.; Shimazu, A.; Hakanen, J.; Salanova, M.; De Witte, H. An ultra-short measure for work engagement: The UWES-3 validation across five countries. Eur. J. Psychol. Assess. 2019, 35, 577-591. [CrossRef]

118. Blustein, D.L. The role of work in psychological health and well-being: A conceptual, historical, and public policy perspective. Am. Psychol. 2008, 63, 228-240. [CrossRef]

119. Graetz, G.; Michaels, G. Robots at Work. Rev. Econ. Stat. 2018, 100, 753-768. [CrossRef]

120. Jung, H.S.; Jung, Y.S.; Yoon, H.H. COVID-19: The effects of job insecurity on the job engagement and turnover intent of deluxe hotel employees and the moderating role of generational characteristics. Int. J. Hosp. Manag. 2021, 92, 102703. [CrossRef]

121. Yeves, J.; Bargsted, M.; Cortes, L.; Merino, C.; Cavada, G. Age and Perceived Employability as Moderators of Job Insecurity and Job Satisfaction: A Moderated Moderation Model. Front. Psychol. 2019, 10, 799. [CrossRef]

122. Cheung, F.Y.-L.; Wu, A.M.S.; Ching Chi (Cindia), L. Effect of job insecurity, anxiety and personal resources on job satisfaction among casino employees in macau: A moderated mediation analysis. J. Hosp. Mark. Manag. 2019, 28, 379-396. [CrossRef]

123. Rainey, H.G. Understanding and Managing Public Organizations; John Wiley \& Sons: Hoboken, NJ, USA, 2009 ; ISBN 0787980005.

124. Jung, C.S. Organizational Goal Ambiguity and Job Satisfaction in the Public Sector. J. Public Adm. Res. Theory 2014, 24, 955-981. [CrossRef]

125. Piccoli, B.; De Witte, H. Job insecurity and emotional exhaustion: Testing psychological contract breach versus distributive injustice as indicators of lack of reciprocity. Work Stress 2015, 29, 246-263. [CrossRef]

126. Hobfoll, S.E. The Influence of Culture, Community, and the Nested-Self in the Stress Process: Advancing Conservation of Resources Theory. Appl. Psychol. 2001, 50, 337-421. [CrossRef]

127. Pap, Z.; Vîrgă, D.; Notelaers, G.; Maricuțoiu, L. A multilevel model of job insecurity and engagement. J. Manag. Psychol. 2020, 35, 529-541. [CrossRef]

128. Jiang, L.; Probst, T.M. Organizational communication: A buffer in times of job insecurity? Econ. Ind. Democr. 2014, 35, 557-579. [CrossRef]

129. Gallie, D.; Felstead, A.; Green, F.; Inanc, H. The hidden face of job insecurity. Work. Employ. Soc. 2017, 31, 36-53. [CrossRef]

130. Greenberg, J. Organizational Justice: Yesterday, Today, and Tomorrow. J. Manag. 1990, 16, 399-432. [CrossRef]

131. Gilboa, S.; Shirom, A.; Fried, Y.; Cooper, C. A meta-analysis of work demand stressors and job performance: Examining main and moderating effects. Pers. Psychol. 2008, 61, 227-271. [CrossRef] 